\title{
Effects of aluminium oxide nanoparticles on bacterial growth
}

\author{
Nina Doskocz ${ }^{1,{ }^{*}}$, Katarzyna Affek ${ }^{1}$, and Monika Załęska-Radziwiłł ${ }^{1}$ \\ ${ }^{1}$ Warsaw University of Technology, Faculty of Building Services, Hydro and Environmental \\ Engineering, Department of Biology, Nowowiejska 20, 00-653 Warsaw, Poland
}

\begin{abstract}
Production and wide application of nanomaterials have led to nanotechnology development but their release to environment and the induction of toxic reactions, affects the natural microbial communities. Therefore, studies on the impact of nanoparticles on microorganisms and environment are required and needed. The aim of this study was to assess the impact of aluminium oxide nanoparticles on the growth of Pseudomonas putida. To compare the harmfulness of different forms of aluminium oxide, the ecotoxicity of its macro-forms was also evaluated in the study. Research showed that the exposure to nanoparticles can negatively influence microorganisms. The $\mathrm{EC}_{50}-16 \mathrm{~h}$ determined in this study was $0.5 \mathrm{mg} / \mathrm{l}$, and NOEC equaled $0.19 \mathrm{mg} / \mathrm{l}$. Nano- $\mathrm{Al}_{2} \mathrm{O}_{3}$ proved to be more toxic to $P$. putida than aluminium oxide. This indicates that the nano-form of a given substance demonstrates different properties and may constitute a far greater danger for the environment than the same substance in the large form. According to EU and US EPA criteria, nano- $\mathrm{Al}_{2} \mathrm{O}_{3}$ proved to be very toxic and highly toxic, respectively. Changes in bacterial communities caused by nanoparticles may affect the normal biological, chemical and nutrient cycle in the ecosystem and the effect triggered by nanomaterials in relation to other organisms is unpredictable.
\end{abstract}

\section{Introduction}

Nanoparticles (NPs) are molecules of dimensions below $100 \mathrm{~nm}$. They are of colloidal particle size and are often smaller than bacterial and eukaryotic cells. Due to their unique physicochemical properties and morphology, such as: high surface to volume ratio, high chemical reactivity, ability to form aggregates, diffusivity, and mechanical strength, NPs have become an attractive material for commercial and technological application. NPs are currently used in many products. Silver (Ag) NPs are incorporated into textiles, clothing, food packaging and other materials for elimination of bacteria, cerium oxide NPs are used in electronics, biomedical supplies, energy, and fuel additives, nano- $\mathrm{TiO}_{2}$ may be found in sunscreens, cosmetics, coatings and paints. Carbon nanotubes have a wide range of uses, ranging from electronic components to composites used to produce of vehicles. Many nanomaterials are used as membrane filters to remove pollution from water $[1,2,3,4,5]$.

*Corresponding author: nina.doskocz@pw.edu.pl 
Production and use of NPs results in their dissemination in the environment through air, wastewater and surface waters. NPs used in cosmetics in Sweden and Denmark are detected in wastewater at about $50 \mathrm{~g}$ per capita and day. Considering city with one million inhabitants the content of these compounds in wastewater would probably reach about $50 \mathrm{t} / \mathrm{d}$ [3]. If not captured during wastewater treatment they can occur in water intended for human consumption. Deposition of NPs in bottom sediments of water reservoirs and their migration through environmental compartments may also have dangerous consequences. Literature data indicates that their increasingly common application and release to environment may trigger toxic reactions, among others, in natural microbial communities.

NPs can change the properties of bacterial cell membrane, influence the permeability and respiration of the bacterial cells, cause damage to DNA and release the toxic ions, but the exact mechanism by which NPs promote this antibacterial ability, is so far the subject of debate [6]. Silver NPs based on the graphene were tested in relation to Pseudomonas aeruginosa. The minimum bactericidal concentration (MBC) was $20 \mathrm{mg} / \mathrm{ml}$, and after $1 \mathrm{~h}$ disintegration of the cell wall was observed [6]. Tamayo et al. observed that silver and copper NPs may penetrate the wall and cell membrane of bacteria Listeria monocytogenes. This led to the separation of the cytoplasmic membrane of the cell wall [8]. Literature data also indicate that NPs proved to reveal the antibacterial properties against Staphylococcus aureus, Escherichia coli, Bacillus subtilis (nano-Cu, nano-ZnO, and nano-Ag) [9, 10, 11], Klebsiella pneumoniae (nano-ZnO) [10], P. aeruginosa (nano$\mathrm{Ag})$ [12], Enterobacter cloacae $\left(\mathrm{Cu}-\mathrm{SiO}_{2}\right.$ nanocomposite) [13], Salmonella typhimurium (Cu NPs/chitosan) [14], L. monocytogenes (Cu NPs) [15], Enterococcus faecalis (nano$\mathrm{TiO}_{2}$ ) [11], and Aeoromonas hydrophila (nano- $\mathrm{Al}_{2} \mathrm{O}_{3}$, nano- $\mathrm{ZrO}_{2}$ ) [16]. The impact of NPs on yeast Candida albicans, and mold Aspergillus niger was also observed [11].

Furthermore, NPs show negative impact on microorganisms involved in wastewater treatment. Zheng et al. proved that zinc oxide NPs had adverse influence on biological processes of nitrogen removal as well as on denitrifying bacteria and microorganisms responsible for phosphorus elimination called PAO (polyphosphate accumulating organisms). Nitrogen removal efficiency decreased from $81.5 \%$ to $75.6 \%$ and $70.8 \%$, when concentrations of nano- $\mathrm{ZnO}$ equaled $10 \mathrm{mg} / \mathrm{l}$ and $50 \mathrm{mg} / \mathrm{l}$, respectively [17]. These results indicate that zinc oxide NPs lead to the disruption of the activated sludge treatment process. In turn, a study published by Choi showed that during wastewater treatment, $1 \mathrm{mg} / \mathrm{l}$ of nanosilver inhibited the growth of autotrophic nitrifying bacteria by about $80 \%$ [18].

In order to determine their potential environmental fate and improve the understanding of the toxicity effects of the aluminum oxide NPs (nano- $\mathrm{Al}_{2} \mathrm{O}_{3}$, $<50 \mathrm{~nm}$ ), the present study examines the antibacterial activity of these NPs against $P$. putida bacteria. The study compares the toxicity of NPs with their bulk counterparts (compounds of the macro-form $-\mathrm{Al}_{2} \mathrm{O}_{3}$ ). Only scarce information is available on fate, transport and effects in the environment of metal-based particles such as nano- $\mathrm{Al}_{2} \mathrm{O}_{3}$. Aluminum oxide NPs are currently used by the military and commercial industries as components of coatings and propellants and their widespread use may result in the release into the environment $[19,20,21]$. 


\section{Materials and methods}

\subsection{Chemicals}

Aluminum oxide NPs (nano- $\mathrm{Al}_{2} \mathrm{O}_{3}$ ), nanopowder $<50 \mathrm{~nm}$ of specific surface of $>40 \mathrm{~m}^{2} / \mathrm{g}$ and aluminum oxide $\left(\mathrm{Al}_{2} \mathrm{O}_{3}\right)$ of purity of $>98 \%$ were obtained from SigmaAldrich. Initial solutions of the tested compounds were prepared in deionised water. Because of the tendency of aggregate formation by the compounds, the obtained solutions of the compounds were sonicated for $30 \mathrm{~min}$ using an ultrasonic disintegrator of MDM-10 type ( $0.4 \mathrm{~kW}$ at a frequency of $20 \mathrm{kHz}$ ). The solutions were diluted (using a medium according to ISO 107122-1994 test procedure for P. putida [22]) with the ratio of geometric progression of dilutions (q) of 2 obtaining solutions ranging from $0.17 \mathrm{mg} / \mathrm{l}$ to $200 \mathrm{mg} / \mathrm{l}$.

\subsection{Bacterial strains}

Heterotrophic gram-negative rods of $P$. putida were isolated from the laboratory activated sludge (Department of Biology, Faculty of Building Services, Hydro and Environmental Engineering, Warsaw University of Technology). Aseptic technique was used throughout the testing process. Constant bacterial cultures were maintained throughout the experimentation and incubations for all tests were conducted for $16 \mathrm{~h}$ at $26^{\circ} \mathrm{C}$.

Bacterial cultures were then subjected to biochemical identification by API procedure. A Gram stain was used to determine whether the bacteria were positive or negative. Oxidase test was performed by adding bacterial smear to filter paper containing oxidase reagent (a mixture of dimethyl-4-phenylenediamine hydrochloride and $\alpha$-naphthol). Colour development was observed within 1 min. Catalase test was performed by adding one drop of $30 \%$ hydrogen peroxide (Aflofarm, Pabianice, PL) to a slide that contained bacterial smear. Bubbling reaction was observed within 1 min. API 20 NE bacterial identification was performed according to manufacturer's instruction (bioMérieux, Durham, NC) [23].

\subsection{Growth inhibition test with Pseudomonas putida}

Growth test with $P$. putida was performed in accordance with ISO 107122-1994 [22]. Growth inhibition $(I)$ was assessed on the basis of optical density values obtained for the samples with $\lambda=610 \mathrm{~nm}$ at the beginning and at the end of the $16 \mathrm{~h}$ test and was calculated according to Eq. 1.

$$
I=\frac{B_{c}-B_{n}}{B_{c}-B_{0}} \cdot 100[\%]
$$

I - Growth inhibition [\%],

$\mathrm{B}_{\mathrm{c}}$ - Optical density of suspension in control sample after $16 \mathrm{~h}$,

$\mathrm{B}_{\mathrm{n}}-$ Optical density of suspension in the sample examined after $16 \mathrm{~h}$,

$\mathrm{B}_{0}-$ Optical density of suspension in control sample in time 0 . 


\subsection{Calculation of $\mathrm{EC}_{50}$ and NOEC}

Effective concentrations $\left(\mathrm{EC}_{50}\right)$ were calculated using probit analysis with $95 \%$ confidence intervals [25]. No observed effect concentrations (NOEC) were determined using ANOVA and Tukey's test [26].

\subsection{Toxicity assessment of compounds}

The assessment of toxicity of the test samples in relation to bioindicators was performed on the basis of the EU criteria-Directive 93/67/EEC (Table 1) and the U.S. Environmental Protection Agency (U.S. EPA) criteria (Table 2) [25, 26].

Table 1. Assessment of toxicity of chemicals in relation to the criteria of their harmfulness to aquatic biocenoses according to EU.

\begin{tabular}{|c|c|}
\hline LC(EC) $_{\mathbf{5 0}}[\mathbf{m g} / \mathbf{l}]$ & Toxicity assessment \\
\hline$<0.1$ & Extremely toxic \\
\hline $0.1-1$ & Very toxic \\
\hline$>1-10$ & Toxic \\
\hline$>10-100$ & Harmful \\
\hline$>100$ & Non-toxic \\
\hline
\end{tabular}

Table 2. Assessment of toxicity of chemicals in relation to the criteria of their harmfulness to aquatic biocenoses according to US EPA.

\begin{tabular}{|c|c|}
\hline $\mathbf{L C}(\mathbf{E C})_{\mathbf{5 0}}[\mathbf{m g} / \mathbf{l}]$ & Assessment of toxicity of chemical \\
\hline$\leq 1$ & Highly toxic \\
\hline$>1-100$ & Moderately toxic \\
\hline$>100$ & Slightly toxic \\
\hline
\end{tabular}

\section{Results and discussion}

The results of growth inhibition test with P. putida are shown on Figure 1. The assessments of ecotoxicity of NPs according to the European Union Directive (93/67/EEC) [25] and the US Environmental Protection Agency (US EPA) criteria [26] are presented in Table 3.

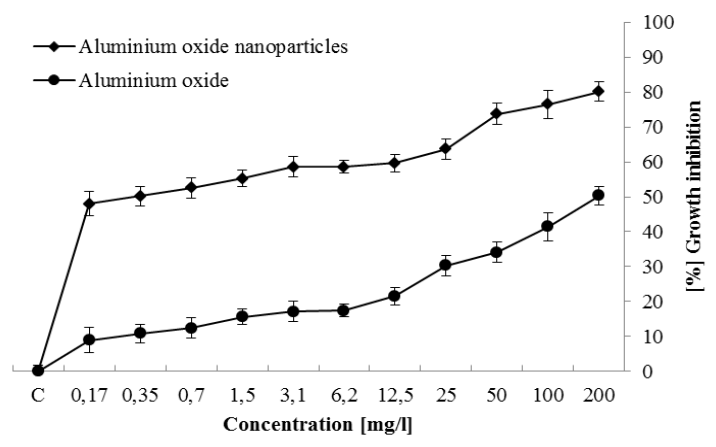

Fig. 1. Effect of nano- $\mathrm{Al}_{2} \mathrm{O}_{3}$ and $\mathrm{Al}_{2} \mathrm{O}_{3}$ on the growth of P. putida. $\mathrm{C}$ - means the control. 
Table 3. Effect of nano- $\mathrm{Al}_{2} \mathrm{O}_{3}$ and $\mathrm{Al}_{2} \mathrm{O}_{3}$ on P. putida. $95 \%$ confidence intervals are shown.

\begin{tabular}{|c|c|c|c|c|c|c|}
\hline \multirow{2}{*}{ Compound } & \multirow{2}{*}{$\begin{array}{c}\text { Toxicity } \\
\text { assessment } \\
\text { criteria }\end{array}$} & \multirow{2}{*}{$\begin{array}{c}\text { Time } \\
{[\mathbf{h}]}\end{array}$} & \multirow{2}{*}{$\begin{array}{c}\mathbf{E C}_{\mathbf{5 0}} \\
(95 \% \\
\text { confidence } \\
\text { intervals) } \\
{[\mathbf{m g} / \mathbf{l}]}\end{array}$} & \multirow{2}{*}{$\begin{array}{r}\text { NOEC } \\
{[\mathrm{mg} / \mathrm{l}]}\end{array}$} & \multicolumn{2}{|c|}{$\begin{array}{l}\text { Ecotoxicity } \\
\text { assessment }\end{array}$} \\
\hline & & & & & $\mathbf{U E}$ & $\begin{array}{c}\text { US } \\
\text { EPA }\end{array}$ \\
\hline Nano- $\mathrm{Al}_{2} \mathrm{O}_{3}$ & \multirow[b]{2}{*}{ Growth } & \multirow[b]{2}{*}{16} & $0.5(0.22-1.03)$ & 0.19 & $\begin{array}{l}\text { Very } \\
\text { toxic }\end{array}$ & $\begin{array}{c}\text { Highly } \\
\text { toxic }\end{array}$ \\
\hline $\mathbf{A l}_{2} \mathbf{O}_{3}$ & & & $\begin{array}{c}295.7 \\
(143.21- \\
241.22)\end{array}$ & 1.9 & $\begin{array}{l}\text { Non- } \\
\text { toxic }\end{array}$ & $\begin{array}{l}\text { Slightly } \\
\text { toxic }\end{array}$ \\
\hline
\end{tabular}

Growth inhibition of $P$. putida was observed during the study. Aluminium oxide NPs inhibited the process in above $50 \%$ at all concentrations tested, except for the lowest $(0.17 \mathrm{mg} / \mathrm{l})$. In the highest tested concentration, inhibition of growth was $80.13 \%$ (Figure 1). $\mathrm{EC}_{50}-16 \mathrm{~h}$ was $0.5 \mathrm{mg} / \mathrm{l}$ and NOEC $-0.19 \mathrm{mg} / \mathrm{l}$ (Table 3 ). The obtained values of $\mathrm{EC}_{50}-16 \mathrm{~h}$ and NOEC-16h showed that P. putida was sensitive to the tested NPs and indicate that aluminium oxide in macro-form has a less impact on bacteria than the compound in the nano-form.

It is worth mentioning that very limited research concerns nano- $\mathrm{Al}_{2} \mathrm{O}_{3}$ antimicrobial evaluation as scientists have mostly explored the antimicrobial properties of Ag NPs [27, 28, 29]. $\mathrm{EC}_{50}$ in studies of Hachicho et al. [30] causing 50\% growth inhibition for Ag NPs was about $250 \mathrm{mg} / \mathrm{l}$. In turn, the experiments conducted by Matzke et al. showed that $P$. putida reacted very sensitively when exposed to nano-silver. $\mathrm{EC}_{50}$ value was between $0.25 \mu \mathrm{g} / 1$ and $3.46 \mu \mathrm{g} / \mathrm{l}$ for the different Ag NPs [27]. An experiment conducted by Gajjar et al. also showed some inhibition of P. putida in the presence of NPs. Toxic doses of the Ag NPs were $0.2 \mathrm{mg} / \mathrm{l}$, for Cu NPs - $10 \mathrm{mg} / \mathrm{l}$, and for Zn NPs - 7-10 mg/1 [29].

Ecotoxicity assessment on the basis of $\mathrm{EC}_{50}$ showed that nano- $\mathrm{Al}_{2} \mathrm{O}_{3}$ are very toxic to bacteria. According to EU criteria, nano- $\mathrm{Al}_{2} \mathrm{O}_{3}$ was very toxic to P. putida. However, according to US EPA criteria aluminium oxide NPs were highly toxic (Table 3).

The obtained results as well as data from literature confirm that the effects of nano$\mathrm{Al}_{2} \mathrm{O}_{3}$ on $P$. putida growth were stronger than those observed for their bulk counterparts (Table 3). The effect of $\mathrm{Al}_{2} \mathrm{O}_{3}$ on P. putida was only slight. $\mathrm{EC}_{50}-16 \mathrm{~h}$ was $295.7 \mathrm{mg} / \mathrm{l}$ and NOEC - $1.9 \mathrm{mg} / \mathrm{l}$. Similar conclusions were obtained by Jiang [30] and Jośko and Oleszczuk [31]. Tested Nanoparticles: $\mathrm{Al}_{2} \mathrm{O}_{3}, \mathrm{SiO}_{2}, \mathrm{TiO}_{2}, \mathrm{ZnO}$ and Ni demonstrated higher toxicity than their bulk counterparts.

Nanocompounds, as a result of their exceptional characteristics, can penetrate cell walls and afterwards the ions can exert toxic effects on cell organelles. The nano size of NPs determines their greater specific surface area than that of their bulk counterparts, due to which they can be more effective in their interactions with the components of bacterial cells and can provide higher risk to the environment than the same substances in their macroforms $[21,30,31,32]$.

\section{Conclusion}

The aim of this study was to investigate the effect of aluminium oxide NPs on the growth of $P$. putida and the obtained data allowed to formulate the conclusion that nano$\mathrm{Al}_{2} \mathrm{O}_{3}$ may inhibit bacterial growth. In accordance with the EU criteria, tested NPs were very toxic to the bacteria. However, according to US EPA, they were highly toxic. 
The obtained results clearly indicate the necessity for ecotoxicity studies of NPs in relation to microorganisms. The study also shows that the currently available ecotoxicity data about compounds in bulk counterparts cannot be used to assess the harmfulness of their nano-form counterparts.

Increasing production of NPs lead to their accumulation in the environment, especially in landfills and landfill leachates and may result in non-target effects on the populations of microbes that play beneficial role in the environment. Negative consequences may concern disturbances in element cycling (carbon, sulfur, nitrogen, etc.), pollutants' degradation and plant growth promotion [29]. There is a constant need for further studies, including not only conventional but also multispecies and molecular tests, in order to explain the mechanisms of NPs' effects on microorganisms and to ensure safety of beneficial microorganisms in the environment.

\section{References}

1. https://www.epa.gov/chemical-research/research-nanomaterials

2. M. Łebkowska, M. Załęska-Radziwiłl, Ochr. Sr. 33, 23-26 (2011)

3. S.K. Brar, V. Mausam, R.D. Tyagi, R.Y. Surampalli, Waste Manage., 30, 504-520 (2008)

4. G. Bystrzejewska-Piotrowska, J. Golimowski, P.L. Urban, Waste Manage. 29, 2587-2595 (2009)

5. P. Mosdorf, E. Karwowska E, A.R. Kunicki, G. Karolczak, Rocz. Ochr. Sr., 13, 1635-1651 (2011)

6. J. R. Morones, J. L. Elechiguerra, A. Camacho, K. Holt, J. B. Kouri, J. T. Ramírez, M. J. Yacaman, Nanotechnology, 16, 2346-2353 (2005)

7. T. He, H. Liu, Y. Zhou, J. Yang, X. Cheng, H. Shi, Biometals., 27, 673-678 (2014)

8. L. A. Tamayo, P. A. Zapata, N. D. Vejar, M. I. Azócar, M. A. Gulppi, X. Zhou, G. E. Thompson, F. M. Rabagliati, M. A. Páez, Mat. Sci. Eng. C-Mater., 40, 24-31 (2014)

9. J. P. Ruparelia, A. K. Chatterjee, S. P. Duttagupta, S. Mukherji, Acta Biomater., 4, 707-716 (2008)

10. A. S. H. Hameed, Ch. Karthikeyan, A. P. Ahamed, N. Thajuddin, N.S. Alharbi, S.A. Alharbi, G.Ravi, Sci. Rep., 6, 1-11 (2016)

11. D. Mitoraj, A. Jańczyk, M. Strus, H. Kisch, G. Stochel, P. B. Heczko, W. Macyk, Photochem. Photobiol. Sci., 6, 642-648 (2007)

12. N. Perkas, G. Amirian, S. Dubinsky, S. Gazit A Gedanken, J. Appl. Polym. Sci., 104, 1423-1430 (2007)

13. Y.H. Kim, D.K. Lee, H.G. Cha, C.W. Kim, Y.S. Kang, J. Phys. Chem. C, 111, 3629-3635 (2007)

14. G. Cárdenas, J. Diaz, M.F. Meléndrez, C. Cruzat, A. García, Polym. Bull., 62, 511-524 (2009)

15. N. Cioffi, L. Torsi, N. Ditaranto, G. Tantillo, L. Ghibelli, L. Sabbatini, T. BleveZacheo, M. D'Alessio, P.G. Zambonin, E. Traversa, Chem. Mater., 17, 5255-5262, (2005)

16. N. Chrzanowska, M. Załęska-Radziwiłł, Interdyscyplinarne zagadnienia $w$ inżynierii i ochronie środowiska (Oficyna Wydawnicza Politechniki Wrocławskiej, 2012)

17. X. Zheng, R. Wu, Y. Chen, Environ. Sci. Technol., 45, 2826-2832 (2011) 
18. O. Choi, K. K. Deng, Jr. Kim, L. Ross, R. Y. Surampalli. Z. Hu, Water Res., 42, 3066-3074 (2008)

19. N. Chrzanowska, M. Załeska-Radziwiłl, Desalination Water Treat., 52, 3680-3689 (2014)

20. J. G. Coleman, D. R. Johnson, J. K. Stanley, A. J. Bednar, C. A. Weiss Jr., R. E. Boyd, J. A. Steevens, Environ. Toxicol. Chem., 7, 1575-1580 (2010)

21. M. Załęska Radziwiłł, N. Doskocz, Desalination Water Treat., 57, 1573-1581, (2016)

22. ISO 107122-1994 Water quality - Pseudomonas putida growth inhibition test (Pseudomonas cell multiplication test).

23. BioMe'rieux, Durham, NC. Instructions for use, API ${ }^{\circledR} 20 \mathrm{E}-18-24$ hour identification of Enterobacteriacae and other non-fastidious gram negative bacteria

24. P. M. Berthouex, L. C. Brown, Statistic for environmental engineers (Lewis Publishers, C.R.C. Press Inc, 1994)

25. Commission Directive 93/67/EEC of 20 July 1993 laying down the principles for assessment of risks to man and the environment of substances notified in accordance with Council Directive 67/548/EEC

26. US EPA (1998). Guidelines for Ecological Risk Assessment, EPA/630/R-95/002F, Risk Assessment Forum, Washington

27. N. Hachicho, P.Hoffmann, K. Ahlert, H. J. Heipieper, Res. Lett., 335, 71-77 (2014)

28. M. Matzke, K. Jurkschat, T. Backhaus, Ecotoxicology, 23, 818-829 (2014)

29. P. Gajjar, B. Pettee, D. W. Britt, W. Huang, W. P. Johnson, A. J. Anderson, J. Biol. Eng., 3 (2009)

30. W. Jiang, Bacterial Toxicity of Oxide Nanoparticles and Their effects on bacterial surface biomolecules (University of Massachusetts - Dissertation, 2011)

31. I. Jośko, P. Oleszczuk, Environ. Sci. Process. Impacts, 15, 296-306 (2013)

32. M. Załęska-Radziwiłł, N. Doskocz, Desalination Water Treat., 57, 1443-1450 (2016) 